\title{
BiçiMSEL, PERDESEL VE RITMIK DÜZENIN BÜTÜNLÜĞÜ AÇISINDAN REGARD DES ANGES
}

\author{
REGARD DES ANGES \\ REGARDING THE INTEGRAL ORGANISATION OF FORM, PITCH AND RHYTHM
}

Yiğit Özatalay*

\section{Öz}

Olivier Messiaen'ın 1944'te bestelediği Vingt Regards sur l'Enfant-Jésus'nun 14. parçası olan Regard des Anges, bestecinin geliştirdiği bütünlüklü poetikanın yetkin bir örneğini temsil eder. Bu makalede söz konusu parçanın biçim, perde ve ritim değişkenleri birbirleriyle ilişkili olarak ve müzikal çözümleme yöntemleri kullanılarak ele alınmıştır. Üç başlıkta irdelenen müzikal uygulamaların genel anlamda düzendüzensizlik salınımı, ek değer, tam-olmayan büyütme/küçültme ve asal sayılar bağlamında birbirleriyle güçlü bağlar kurduğu görülmüştür. Çalışmanın amacı, temel kompozisyonel bileşenlere tutarlı ve uyumlu bir yaklaşım sergileyen Messiaen'ın müzikal diline ışık tutmak, bestecinin poetikasındaki birlik ve bütünlük vurgusunu Regard des Anges aracılı̆ııla öne çıkarmaktır.

Anahtar Kelimeler: Olivier Messiaen, Vingt Regards, Regard des Anges, Bütünlük.

\section{Abstract}

Regard des Anges, composed by Olivier Messiaen in 1944 as the 14th piece of Vingt Regards sur l'EnfantJésus, represents a competent example of the integral poetics developed by the composer. In this article, the parameters of form, pitch and rhythm are handled in correlation to each other under musical analysis methods. It's approved that three titles in total establish strong relationships with each other, generally about the oscillation between order and disorder, added value, inexact augmentation/diminuation and prime numbers. The aim of this article is to enlighten Messiaen's musical language which shows a consistent and harmonic approach to the basic compositional components, and to drive the composer's emphasis on unity and integrality forward through Regard des Anges.

Keywords: Olivier Messiaen, Vingt Regards, Regard des Anges, Integrity.

\section{Giriş}

Piyano için bestelenmiş 20 dinsel parçadan oluşan Vingt Regards sur l'Enfant-Jésus (1944), Olivier Messiaen’ın ilk dönem müziğinde önemli bir adım olarak karşımıza çıkar. İlk kez Yvonne Loriod'nun seslendirdiği Visions de l'Amen (1943) ve Trois Petites Liturgies (1943-1944) yapıtlarından hemen sonra bestelenmiş olan bu müzik, Fransız piyanistin virtüözlüğünün besteciye verdiği ilhamı açıkça kendisinde taşır.

\footnotetext{
Araştırma Makalesi // Başvuru tarihi: 01.03.2021 - Kabul tarihi:24.06.2021.

* Öğr. Gör., İstanbul Bilgi Üniversitesi, Sosyal ve Beşeri Bilimler Fakültesi, Müzik Bölümü, yigit.ozatalay@bilgi.edu.tr, https://orcid.org/0000-0002-4647-5728.
} 
Yapıtın kuruluşu teolojik kavramlara sıkı sıkıya bağlıdır; dinsellik hem biçimsel (bölümlerin dinsel anlama sahip sayılarla -özellikle 7 asal sayısı ile- ilişkilendirilmesi nedeniyle [Pople, 1998:93]) hem de tematik olarak (parçalar zinciri içinde yinelenen Thème de Dieu, Thème d'amour, Thème de l'Etoile et de la Croix gibi sabit temaların varlığı nedeniyle [Messiaen, 1944:i]) yoğun bir biçimde belli edilir.

Vingt Regards zincirinin biçimine genel olarak baktığımızda Thème de Dieu (Tanrı teması) içeren parçaların $(1,5,6,10,11,15,19$ ve 20$)$ temaya yüklenen dinsel anlama koşut olarak, müzikal anlamda da öne çıktığını görürüz. Bu temayı içermeyen parçalarsa üçlü olarak gruplanırlar: 2-3-4, 7-8-9, 12-13-14 ve 16-17-18. Her üçlü gruba geçişte müziğe yeni bir hareket sağlayan biçimsel belirginliği özellikle 12. ve 16. parçalarda açıkça duyabiliriz. 14. parça olan Regard des Anges, 3. üçlü grubun sonunda yer alır. Messiaen'ın üretiminde önemli bir yeri olan kuş şarkılarının zincir içerisinde dekoratif bir karakterden daha solistik ve özgür bir role doğru dönüşümünü izlemek mümkündür, ancak bu durum 14. parça için çok da geçerli değildir. Çünkü düzenli bir 2/4 tartımı -özellikle 78. ölçüden itibaren başlayan ikinci bölümde- bu figürleri güçlü bir biçimde kontrol eder.

Regard des Anges, birbirinden olabildiğince farklılaştırılmış, peş peşe sıralanmış, ama aynı zamanda birbirleriyle ilişkilendirilmiş, oranlanmış ve dengelenmiş dokulardan oluşmaktadır.

Büyük resmi görebilmek için ilk olarak bu biçimsel düzeni çözümleyelim.

\section{Biçim}

4,5 dakikalık bu parça, yaklaşık olarak ortadan (2'30") ikiye bölünmüş bir biçimde incelenebilir. Bu bölünmeyi toplam sayfa sayısına bakarak da görebiliriz: 5 + 5. İlk bölüm (ö. 1-77) birbirlerinden ayrıştırılmış ve blok olarak peş peşe sıralanmış olan 5 doku ile inşa edilmiştir. İkinci bölüm ise malzemesini kuş şarkılarından alır (ö. 78-126) ve başlangıçtaki malzemenin dönüşmüş bir halini kullanan coda (ö. 133-155) ile sona erer.

İlk bölümün A (ö. 1-4), B (ö. 5-6), C (ö. 7-8), D (ö. 9-13) ve E (ö. 14-18) olarak harflendireceğimiz 5 dokusu, her şeyden önce ritmik düzen açısından sınıflandırılabilir: Ritmik açıdan $A$ ve $C$ düzenli, bağdaşık (4 ve katları üzerine kurulu ritimler ve yinelemeleri) ve döngüsel bir karaktere sahipken, $B$ ve $D$ düzensiz ve ayrışıktır. Düzen ve düzensizlik arasındaki bu denge (A- 
B-C-D sırası) iki karşıtlık arasındaki sentezi simgeleyen E dokusu ile son bulur. Bütün bölüm, aynı sıranın üç kez sergilenmesini içerir.

Bu bölümdeki biçimsel işlem, keskin bir düzen içermeyen üç dokunun, yani $B, D$ ve E'nin her yinelemede biraz daha uzatılmasıdır (Joos, 2002:78). Buna göre, ilk yinelemedeki (ö. 19-43) biçim A - B' (B + 2 ölçü) - C - D' (D + 4 ölçü) - E' (E + 1 ölçü) olarak, ikinci yinelemedeki (ö. 44-77) biçim ise A - B" (B' + 1 ölçü) - C - D" (D' + 5 ölçü) - E" (E' + 3 ölçü) olarak özetlenebilir.

Bu işlemler aklımıza doğrudan Messiaen'ın "ek değer" ve "tam-olmayan büyütme" kavramlarını getirecektir kuşkusuz. Vingt Regards ile aynı yıl, 1944'te yayınlanmış olan Müzikal Dilimin Tekniği adlı kitabında bestecinin ilk sayfalarda verdiği ritmik örnekler aslında bu yaklaşımın bir mikro modelidir (Messiaen, 1944:9). Regard des Anges'nin ilk bölümünde gördüğümüz biçimsel kuruluş, "ek değer" yoluyla elde edilen "tam-olmayan büyütme" nin büyük ölçekteki uygulamasıdır. Başka bir deyişle ritmik bir fikir, biçimsel kuruluşa yansıtılmıştır: B, D ve E dokuları ek ölçüler yoluyla artarken $A$ ve $C$ değişmezler.

Kuş şarkılarının egemen olduğu ikinci bölüm de birinci bölüm gibi kesitlere ayrılabilir: F (ö. 78-87), F' (ö. 88-104) ve F" (ö. 105-126). Her ne kadar F harfiyle, yani öncekilerden farklı bir harfle adlandırmış olsak da, bu bölüm aslında A ve D dokularının kuş şarkılarıyla harmanlanarak hafifçe dönüştürülmüş, gizlenmiş versiyonlarını içerir. Dahası, kesit uzunluklarına uygulanan uzatmalar (ek ölçüler) bu bölümde de uygulanmıştır. Piyanistin özellikle sol elinde somutlaşan biçimsel süreci özetlersek; $F$ kesiti dön. A (6 ölçü) + dön. D (5 ölçü), $F^{\prime}$ kesiti dön. A (8 ölçü) + dön. D (9 ölçü), $F^{\prime \prime}$ kesiti ise dön. A (9 ölçü) + dön. D (13 ölçü) dokularından meydana gelir (dön. = dönüştürülmüş).

A dokusuna oranla D’nin daha az dönüştüğünü eklememiz gerekir. Her şeyden önce, D’nin her görünümünde sağ elin de dokuya destek olması (ö. 84-85, 96-97, 114-115) bize ilk bölümdeki D’nin başlangıçlarını vermektedir. Ayrıca, son ölçüsü eksik olan D dışında, ritimler ve nota süreleri tam tamına aynıdır. Bu küçük eksikliğin de tutarlı bir sebebi vardır: Messiaen, 127. ölçüde gelmesi gereken uzun ses yerine, benzer bir etki yaratan otuzikilik nota silsilesini getirir. Böylece hem ikinci bölümden çıkıp coda'yı (G) hazırlayan bir ara müziği yaratır, hem de dahice bir ulama ile A dokusunu resmetmiş olur. 
Parça, E dokusundan türeyen malzemenin sert yinelemelerinden oluşan bir coda (G) ile son bulur. 133. ölçünün altına yazılmış olan La stupeur des anges s'agrandit yani "Meleklerin şaşkınlığı/korkusu büyür" tümcesini simgeleyen aşamalı crescendo ve ritmin sert düzeni, bu kez örtülü bir biçimde görünse de, ilk bölümün $C$ dokusunu anımsatır bize.

Ritimde oldukça etkili bir güce sahip olan asal sayılar, Messiaen tarafından kompozisyonun biçimsel kuruluşunda da kullanılır. Her şeyden önce 5 sayısı (ki besteci bu sayıdan Ritim, Renk ve Kuşbilimi kitabında "her elin sahip olduğu parmak sayısı" olarak söz eder [Baggech, 1998:296]) bu müzikteki temel dokuların sayısıdır ve 3 (ki çok daha yaygın kullanılan bir asal sayıdır) kez sergilenirler. Regard des Anges'nin başlangıcında 5 sayısının altı çizilirken, parçayı sonlandıran sayı ise 7'dir. Bu sayı, Vingt Regards zinciri boyunca Thème de Dieu içeren temel parçaların toplam sayısı olması dışında, Regard des Anges parçasının numarası olan 14 sayısıyla da yakından ilişkilidir $(7 \times 2)$. Dolayısıyla Messiaen'ın 14 . parçayı $7 / 8^{\prime}$ lik ölçüler silsilesi ile kapatması bir tesadüf olmamalıdır.

Asal sayıların büyük ölçekte biçime yansımalarının bir başka görünümü de ikinci bölümde karşımıza çıkar. Bu bölümün üç kesiti sırayla 11, 17 ve 23 ölçüye sahiptir (ö. 78, 88 ve 105). Yalnızca, yukarıda değindiğimiz 127. ölçüdeki ulama nedeniyle, son kesitten bir ölçü eksiltilmiştir. Ancak Messiaen, en sonda, yeniden altını çizer 23 sayısının önemini: Coda, 23 tane 7/8'lik ölçüden oluşmuştur (ö. 133-155). Ek olarak bu 23 ölçü, asal sayıları temel alan bir bölünme ile daha da belirginleştirilmiştir: Coda'da gerçekleşen ses menzilindeki aşamalı genişleme (ki bu genişlemenin toplam ölçü sayısı yine bir asal sayı olan 19'dur), sol elin sürekli inmek yerine düzensiz aralıklarla yukarı çıktığı noktalar sayesinde daha organik ve asimetrik bir biçime kavuşmuştur.

\section{Perdesel Düzen}

Parçadaki perdesel düzen (pitch organization), temel fikri oluşturan 5 doku arasındaki azami farklılaştırma ile koşut düşünülebilir. Bir sınıflandırma yaparsak; A, C ve D modlardan, B ve E ise "akorlar teması"ndan (Thème d'accords) oluşmaktadır. 
Öncelikle, A dokusunun modu Messiaen'ın “sınırlı aktarıma tabi 7. mod”u ile güçlü bir benzerlik taşır. Görsel 1'de sırasıyla bestecinin 7 numaralı modu (Messiaen, 1944:94) ile A dokusunun (ö. 1-4) modu gösterilmektedir.

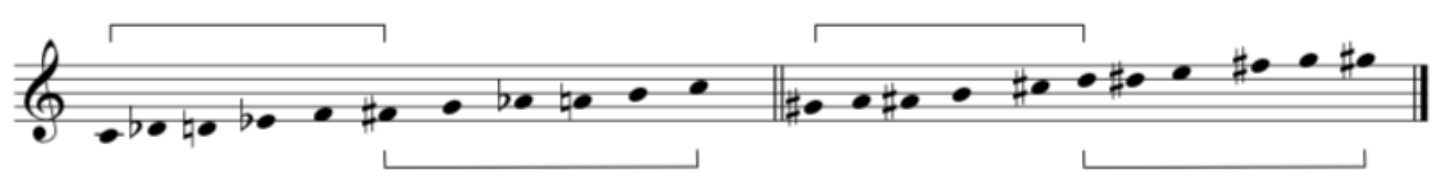

Görsel 1. Messiaen'ın 7. modu ile Regard des Anges'deki A dokusunun modu arasında karşılaştırma.

Görüldüğü üzere 7. mod, (012356) ses kümesinin aktarımsal simetrisi (transpositional symmetry) üzerine kurulurken, A dokusunun modu ise aynı perdesel içeriğin (4 yarım ve 1 tam perde) hafifçe farklı düzenlenişlerine sahip iki ses grubunun oluşturduğu kusurlu bir simetriye, Messiaen'ın deyimiyle “lezzetli bir asimetriye, cazip bir topallamaya” (Baggech, 1944:298) sahiptir. Başka bir deyişle, 7. modda bütünsel bir kromatiklik elde etmek için bir artmış dörtlü (Mi - Si bemol) eksikken, A dokusunun modunda bir tam dörtlü (Do - Fa) eksiktir. 7. modla kurulan böylesine güçlü bir benzerliğin hem Regard des Anges'nin parça numarasıyla (14), hem de parça sonundaki 7/8 tartımına parça başlarken de bir karşılık aranmasıyla ilgisi olmalıdır.

C ve D dokuları ise içerdikleri ses grupları bağlamında kusursuz bir simetriye sahiptir. Dahası, C dokusunda ses malzemesinin ellere dağılımı da simetriktir. Görsel 2'de yukarı bakan saplar sağ elin, aşağı bakan saplarsa sol elin çaldığı notaları göstermektedir.

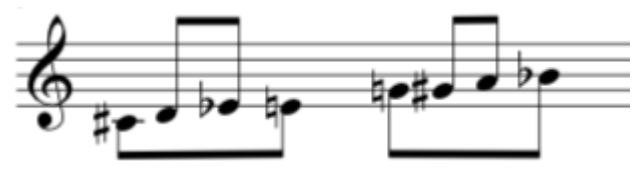

Görsel 2. Messiaen, Regard des Anges, C dokusunun (ö. 7-8) ses malzemesindeki simetri.

Partisyonda canon rythmique sözüyle eşlik edilen $\mathrm{D}$ dokusu da çokboyutlu bir simetri sahibidir. Bu heterofonik doku, her biri farklı bir artmış dörtlüden oluşan 3 kanonik çizgiden oluşmaktadır (bkz. Görsel 3). 
SDÜ ART-E

Güzel Sanatlar Fakültesi Sanat Dergisi

Haziran'21 Cilt:14 Sayı:27

ISSN 1308-2698

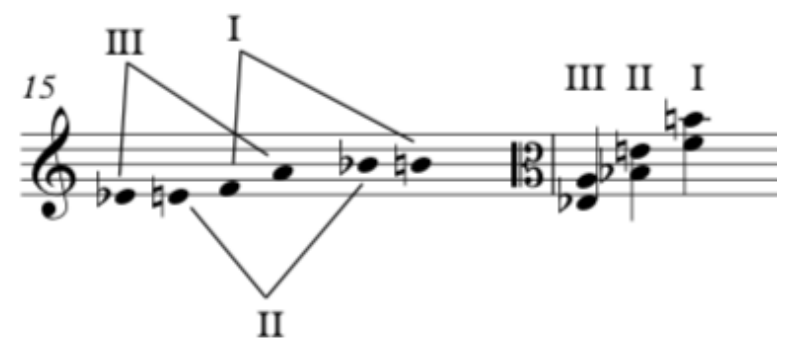

Görsel 3. Messiaen, Regard des Anges, D dokusunun (ö. 9-13) ses malzemesindeki simetri.

Şu ana kadar perdesel düzen bağlamında sözünü ettiğimiz dokuların üçünde (A, C ve $D)$ de düşey/armonik anlamda küçük ikili aralığı ve bileşikleri (küçük dokuzlu, küçük onaltılı vd.) belirgin olarak görülmektedir.

B ve E dokularındaki ses kuruluşunu açıklamak içinse Vingt Regards zincirinde belli aralıklarla yinelenen "akorlar teması"na (Thème d'accords) atıfta bulunmak gerekir (Joos, 2002:78). Bu tema, zincirde yinelenen diğer temalar (Thème de Dieu, Thème d'amour, Thème de I'Etoile et de la (roix) gibi dinsel bir anlam taşımaz; ancak 20 parça boyunca en yaygın kullanılan temadır (6, 14, 15, 16, 17, 18 ve 20 numaralı parçalarda duyurulur [Burger, 2009:53]). Fa diyez, Sol diyez, Si bemol ve Si bekar perdelerini iki kez olmak üzere, 12 perdenin hepsini kullanır. Temayı ikiye bölerek 8 farklı notaya sahip iki ses grubu elde edebiliriz. Bunlara x ve y diyelim (bkz. Görsel 4).
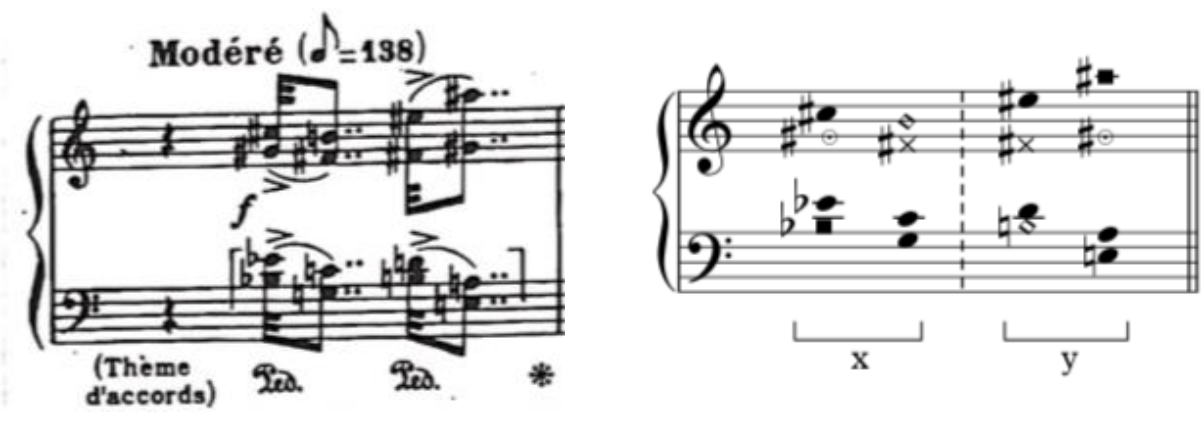

Görsel 4. Messiaen, Regard des Anges, akorlar teması (ö. 5) ve çözümlemesi.

Partisyon üzerinde fractionnement du thème d'accords sözü ile eşlik edilen $\mathrm{E}$ dokusu, $\mathrm{x}$ ve y kümelerinden alınmış düzensiz parçalardan oluşur. Görsel 5'te kesinti yapılmış parçalar eksi (-), ekleme yapılmış parçalar ise artı (+) işaretiyle gösterilmiştir. 
SDÜ ART-E

Güzel Sanatlar Fakültesi Sanat Dergisi

Haziran'21 Cilt:14 Sayı:27

ISSN 1308-2698
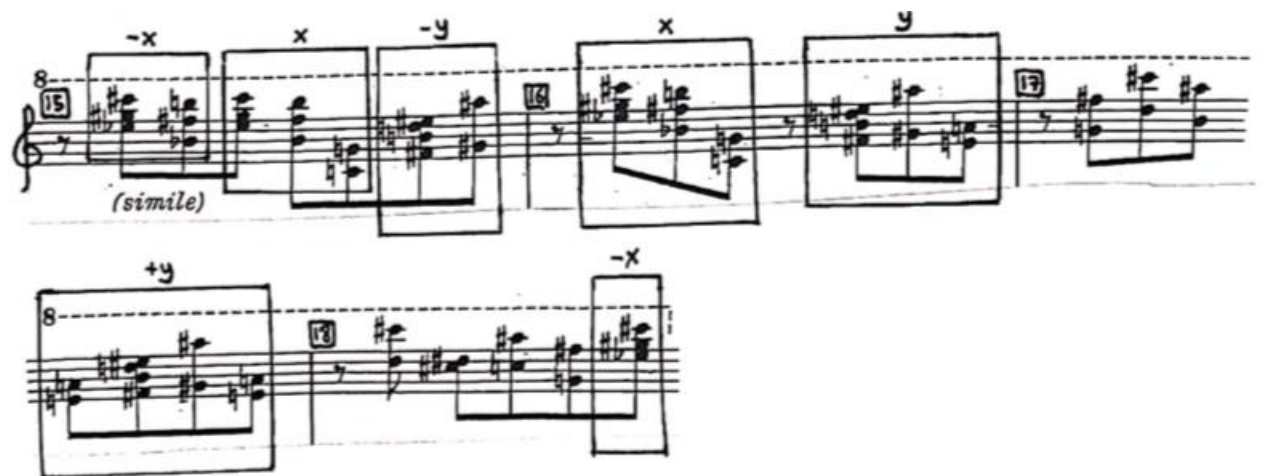

Görsel 5. Messiaen, Regard des Anges, E dokusunun (ö. 14-18) perdesel çözümlemesi.

\section{Ritim}

Müzikal Dilimin Tekniği kitabının ses yüksekliğinden önce ilk olarak ritim değişkenine yer vermesinden de anlaşılabileceği gibi, Messiaen'ın müzik dilinde ritim kavramı her zaman önemli bir yer tutmuştur. Örneğin, 120 Deçi-Tala (Hint ritimleri) arasında 93.sü olan Ragavardhana, bu kitapta bestecinin kendi kompozisyon tekniğini açıklamak için başvurduğu ilk terimlerden biridir (Messiaen, 1944:9). Bir diğer önemli kitabı olan Ritim, Renk ve Kuşbilim üzerine Inceleme'de Messiaen'ın Ragavardhana üzerine yaptığı açıklamalara bir göz atarsak, onun ilgi alanına giren temel ritmik kavramları da görmüş oluruz:

Bu ritim, en zengin ritimlerden biridir, çünkü 5 ilkenin hepsini de kullanır:

a) Baştan sona ritmik büyütme ve ritmik küçültme

b) Ritmik çözülme (disassociation) ve ritmik pıhtılaşma (coagulation)

c) Tam-olmayan büyütme ve küçültme

d) Ek değer

e) Ters döndürülemeyen ritimler. (Baggech 1998: 301)

Ragavardhana'yı anlatan bu maddelere bir de asal sayıların kattığı değeri eklersek -ki söz konusu ritim 19 ile ilişkilidir-Messiaen'ın ritim dilinin hemen hemen tüm başlıklarını elde etmiş oluruz.

Messiaen, ritim anlayışının vazgeçilmez ilkelerinden olan ritmik büyütme ve küçültme tekniklerini genellikle "ek değer" ile birlikte kullanır. Illk örnek Regard des Anges'nin 6. ölçüsünden verilebilir: Bu ölçüde uzatma noktaları taşıyan ritim, kendinden hemen önce gelen ritmin tam 
olarak büyütülmüş halidir. Tam büyütmenin bir başka örneğine ise 74. ve 77. ölçüler arasında, sol elde rastlarız (bkz. Görsel 6).

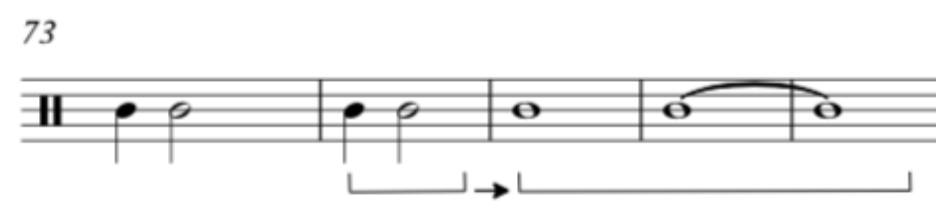

Görsel 6. Messiaen, Regard des Anges, ö. 74-77, sol el ritmindeki tam büyütme örneği.

Deçi-Tala (Hint ritimleri) arasında 105.si olan Candrakala ritmi de ilk defa 11. ve 13. ölçüler arasında kullanılır ve tam büyütmenin ek değerle kullanılmasına bir örnek oluşturur.

Regard des Anges'de kullanılan diğer iki Hint ritminde (ters Ragavardhana [0̈. 9-11] ve Laksmiça [ö. 33-35]) ise ek değerin işlevi ritmik büyütme ve küçültmelerin oranlarını bozarak onları tam-olmayan (inexact) hale getirmektir. Hatırlatalım ki, büyük ölçekte ölçü sayılarına uygulanan ve biçime damga vuran, tam olarak bu ritmik işlemdir (tam-olmayan büyütme / ek değer).

Coda kesitinin ritmi de daha önce duyurulan bir malzemenin tam-olmayan küçültmeye tabi tutulmasıyla elde edilir. Bu malzeme, E dokusunun sol elindeki ritimdir. Küçültme işlemi son sayfanın ilk sisteminde (ö. 131-133) açıkça görülebilir (bkz. Görsel 7).

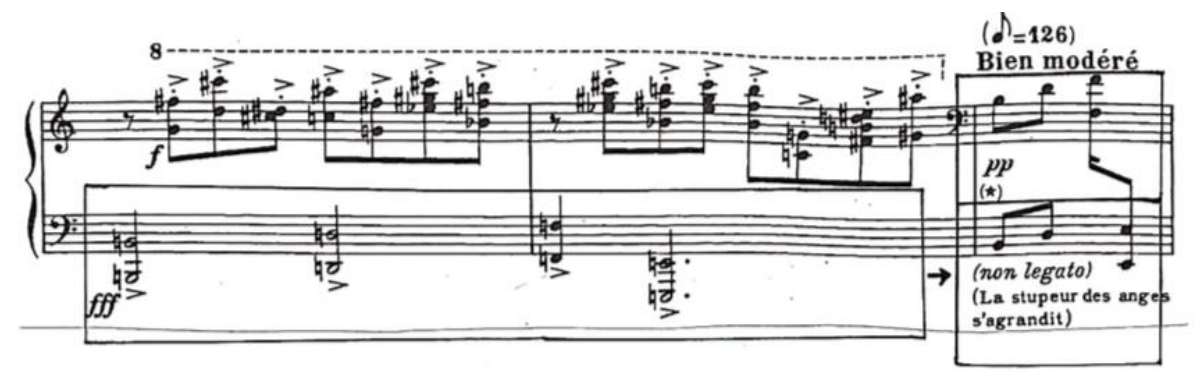

Görsel 7. Messiaen, Regard des Anges, ö. 131-133, E dokusunun sol elindeki ritmik küçültme işlemi.

Ritmik çözülme işlemini yine Ragavardhana'da görmek mümkündür. Bu ritim özgün biçiminde değil, noktalı dörtlüğü 3 sekizliğe bölünmüş bir halde, yani daha parçalı/çözülmüş bir durumda kullanılmıştır. Bu çözülme, ritmi oluşturan iki küme arasındaki akrabalığı da görmemize yardımcı olur (bkz. Görsel 8). 
SDÜ ART-E

Güzel Sanatlar Fakültesi Sanat Dergisi

Haziran'21 Cilt:14 Sayı:27

ISSN 1308-2698

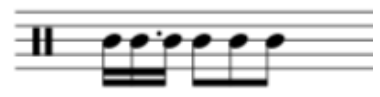

Görsel 8. Ritmik çözülme uygulanmış Ragavardhana içindeki iki akraba küme.

Pıhtılaşma ise çözülmenin tam tersidir; küçük ritmik değerler büyük bir değer oluşturmak için birleşirler. Regard des Anges'nin 6. ölçüsünde "ek değer"i çıkarılarak pıhtılaşmış bir Candrakala ritmi bulmak mümkündür. Görsel 9'da sırasıyla 6. ölçüdeki ritim ve özgün Candrakala ritmi verilmiştir.

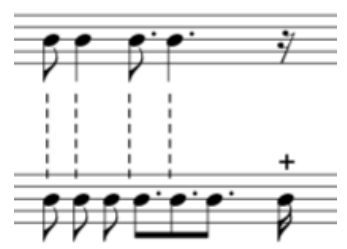

Görsel 9. Messiaen, Regard des Anges, ö. 6, Candrakala üzerindeki ritmik pıhtılaşma.

Parçadan vereceğimiz ilk örnek yine Ragavardhana olabilir. Bu ritmi oluşturan ilk küme ters döndürülemeyen, yani simetrik bir ritimdir (bkz. Görsel 8). İkinci örneğimiz ise daha gizlidir, çünkü ölçülerin eşit şekilde bölünmesi ile simetrisi bulanıklaşmıştır. 7/8 tartımlı coda'daki sert ostinato aslında 2 adet ters döndürülemeyen ritimden oluşmuştur, üstelik ikisi de aksanlı olan sesi merkezine alır (bkz. Görsel 10).

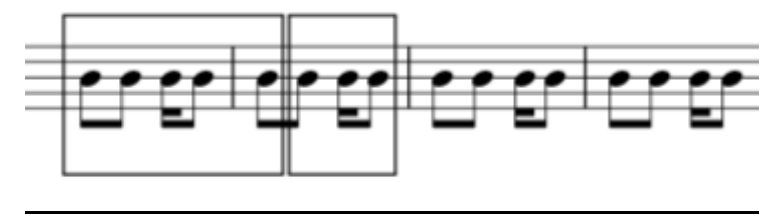

Görsel 10. Messiaen, Regard des Anges, Coda'da (ö. 133-155) iç içe geçmiş olan iki simetrik (ters döndürülemeyen) ritim.

Regard des Anges'nin biçimsel kuruluşunda asal sayıların işlevinden bahsetmiştik. Küçük ölçekte ise iki Hint ritmindeki varlığından söz edebiliriz bu sayıların: 19 tane onaltılık nota uzunluğundaki Ragavardhana ve 17 tane onaltılık nota uzunluğundaki Laksmiça. Candrakala ise 16 tane onaltılık uzunluğundadır. Ancak ne zaman ki üçü birden bir ritmik zincir oluştururlar, o zaman 17 hamleli düzensiz bir ostinato elde edilir (bkz. Görsel 11). 

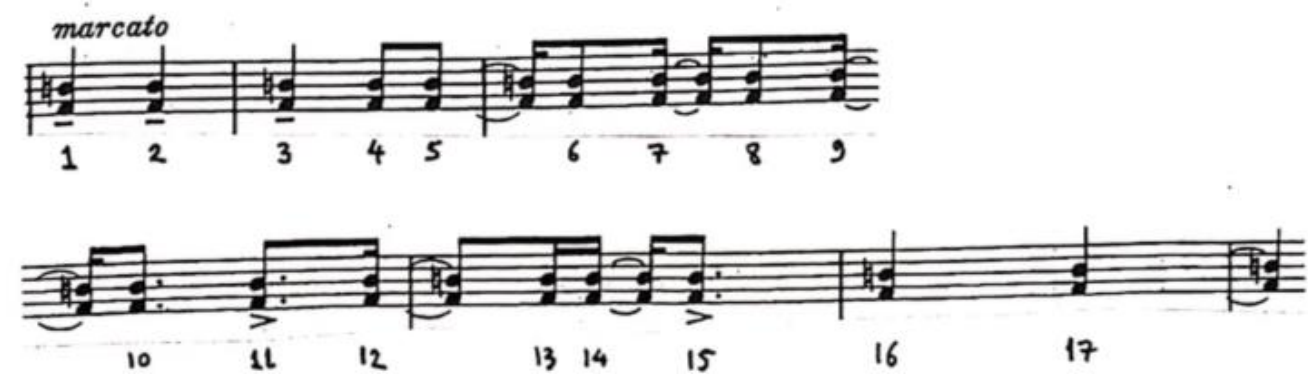

10

11

1314

15

16

17

Görsel 11. Messiaen, Regard des Anges, ö. 29-35, Ragavardhana, Candrakala ve Laksmiça'nın art arda eklenmesinden oluşan ritmik zincir.

Yukarıda belirttiğimiz ritmik zincir sayesinde D dokusu, parçadaki en güçlü ve en yoğun ritmik fikre sahiptir (Joos, 2002:78). Üç Hint ritminin arka arkaya sıralanmasıyla elde edilen bu ritmik zincirde Messiaen'ın favorisi olan Ragavardhana, ilk sıradaki ritim olmasının yanı sıra ters döndürülmüş olmasıyla da dikkat çeker. Bu işlemin nedeni, Ragavardhana ve Candrakala arasındaki bütünleşme sayesinde zincirde bir çizgisellik/doğrusallık yaratmak, ritmik değerlerin aşamalı olarak artıp eksilmesini sağlayarak bir büzüşme-genleşme döngüsü meydana getirmektir.

Bu çok boyutlu ritmik zincir, Messiaen'ın Chants de tere et de ciel (1938), Les corps glorieux (1939) ve Visions de l'Amen (1943) gibi Vingt Regards'ı önceleyen yapıtlarında da kullandığı favori bir malzemedir (Pople, 1998:21). Hatta bu malzeme, Görsel 12'de kutu içerisinde gösterdiğimiz üzere, bestecinin en "popüler" yapıtlarından olan Quatour pour la fin du Temps'te (Zamanın Sonu için Dördül) piyanistin çaldığı ilk ritmik malzemenin ta kendisidir (Messiaen, 1944:26). 
SDÜ ART-E

Güzel Sanatlar Fakültesi Sanat Dergisi

Haziran'21 Cilt:14 Sayı:27

ISSN 1308-2698

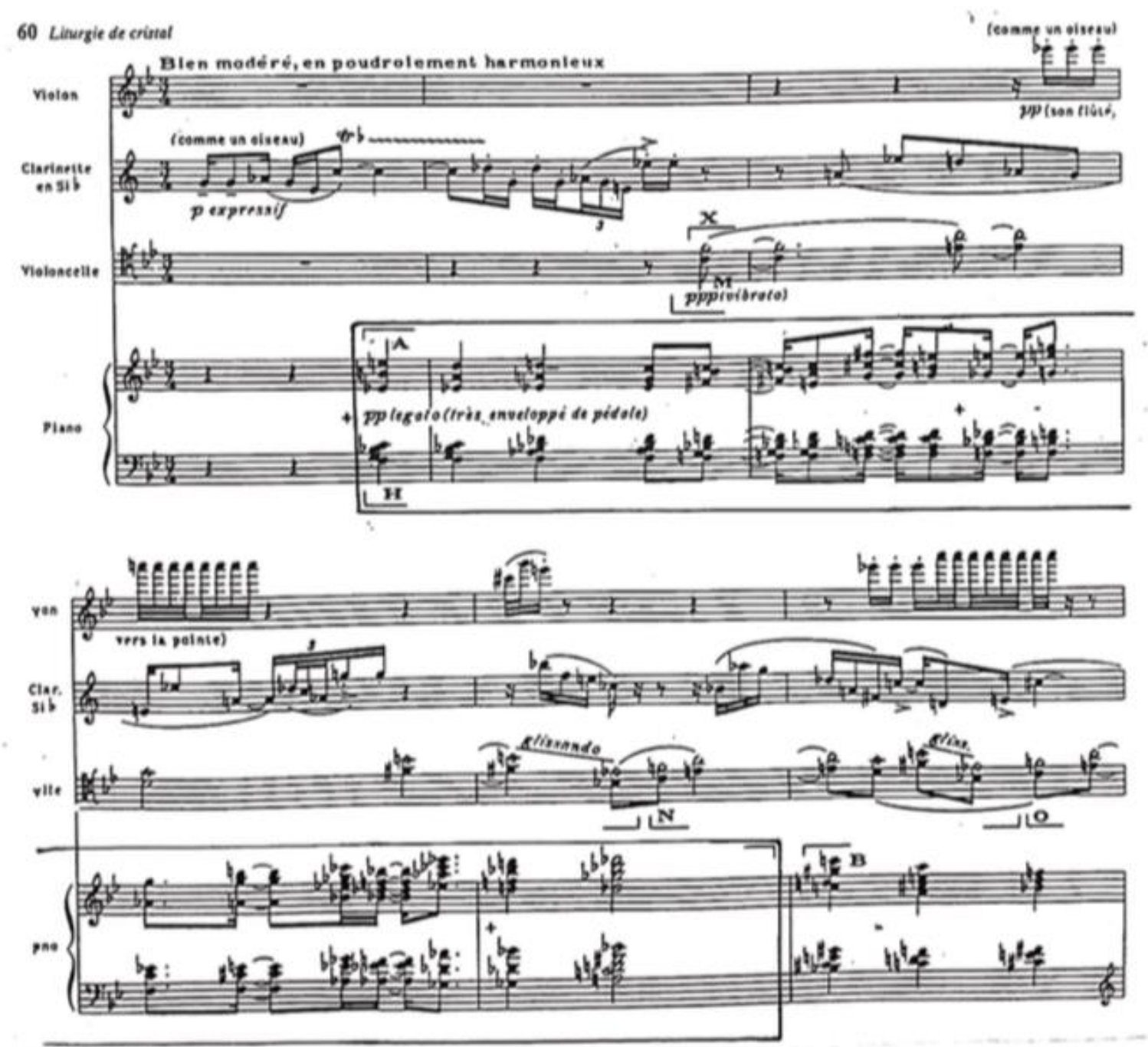

Görsel 12. Messiaen, Quatour pour la fin du Temps'in (1941) ilk ölçüleri.

\section{Sonuç}

Messiaen'ın Regard des Anges'sindeki biçimsel, perdesel ve ritmik düzen, aralarındaki organik bağlar ve ortaklıklar sayesinde kompozisyonel yapıyı birbirlerine destek olarak ayakta tutan üç ayağa benzemektedir.

Kompozisyonel estetikte sıklıkla karşımıza çıkan "bir makro ritim olarak biçim” yaklaşımı, Messiaen'ın bu müziğinde göze çarpan ilk bütünsel niteliktir. Öncelikle, ilk bölümü biçimlendiren 5 doku, ritmik açıdan düzenli ve düzensiz olarak sınıflandırılabilmekte, düzen ve düzensizlik 
arasındaki sarkaçvari gidiş-geliş E dokusunun senteziyle son bulmaktadır. (Benzer türden bir gidişgeliş fikri, D dokusunun ritmik zincirindeki büzüşme-genleşme döngüsünde de karşımıza çıkar.) Bestecinin müzik diline dair ikinci ve daha özgün bir ritim-biçim ilişkisi ise "ek değer" ve "tamolmayan büyütme" kavramlarının aynı bölümün biçimsel sürecine yansıtılmasıdır. Son olarak asal sayılar, ritmik ve biçimsel düzenin ikisinde de çok önemli bir rol oynamaktadır.

Tüm ritim-biçim ilişkilerinin perdesel düzen bağlamında da işlendiğini ve desteklendiğini görürüz: 5 doku arasındaki gidiş-geliş, iki perdesel malzeme (modlar ve "akorlar teması") arasında da gerçekleşir: Modal malzemeler kusurlu ya da kusursuz olarak simetrikken (yani düzenliyken), "akorlar teması" ise asimetrik ve düzensiz bir malzeme sunmaktadır. Bu temanın E dokusundaki işlenme biçimini ise ritmik ve biçimsel düzlemde uygulanan "tam-olmayan büyütme/küçültme" işlemlerinin oldukça yaratıcı bir yansıması olarak algılamak mümkündür. Son olarak, Messiaen'ın 7. moduyla kurulan güçlü benzerlik, Regard des Anges'nin parça numarasıyla (14) ve parça sonundaki 7/8 tartımına parça başlarken de bir karşılık aranmasıyla ilişkili olduğu kadar asal sayıların perdesel düzene örtük bir yansıması olarak da okunabilir.

Biçim, perde ve ritim gibi temel kompozisyonel bileşenler/değişkenler arasında ortaya koyduğumuz bu ortaklıklar ve "armoni”, Messiaen'ın poetikasındaki bütünlük vurgusunun bir göstergesidir. Regard des Anges'yi ayakta tutan ve güçlü kılan, tıpkı organizmayı ayakta tutan organların çalışma sistemini andıran, sistematik bir bütünlüktür. 


\section{Kaynakça}

Baggech, M. (1998). An English Translation of Olivier Messiaen's Traite de rythme, de couleur, et d'ornithologie, Yayınlanmamış Doktora Tezi, 1. Cilt, Norman: The University of Oklahoma.

Burger, C. P. (2009). Olivier Messiaen's Vingt Regards sur I'Enfant-Jésus: Analytical, Religious and Literary Considerations, Yayınlanmamış Doktora Tezi, University of Texas at Austin.

Joos, M., Pierre-Laurent Aimard'ın işbirliğiyle (2002). "Olivier Messiaen: Vingt Regards sur I'Enfant-Jésus: analyse, perception et interprétation", Analyse Musicale, Paris, Sayı 44, s. 67-98.

Messiaen, O. (1944). Tecnica del mio linguaggio musicale, çev. Lucia Ronchett, Paris: Alphonse Leduc.

Messiaen, O. (1944). Vingt Regards sur l'Enfant-Jésus, Paris: Durand S.A.

Pople, A. (1998). Messiaen: Quatour pour la fin du Temps, Cambridge University Press.

\section{Görsel Kaynaklar}

Görsel 1. Messiaen, O. (1944). Tecnica del mio linguaggio musicale, çev. Lucia Ronchett, Paris: Alphonse Leduc. (7. mod Messiaen'ın Müzikal Dilimin Tekniği kitabından alınmış, A dokusunun modu ise bizim tarafımızdan eklenmiştir.)

Görsel 2. Messiaen, O. (1944). Vingt Regards sur l'Enfant-Jésus, Paris: Durand S.A. (Görsel, C dokusunun perdesel malzemesi baz alınarak bizim tarafımızdan oluşturulmuştur.)

Görsel 3. Messiaen, O. (1944). Vingt Regards sur l'Enfant-Jésus, Paris: Durand S.A. (Görsel, D dokusunun perdesel malzemesi temel alınarak bizim tarafımızdan oluşturulmuştur.)

Görsel 4. Messiaen, O. (1944). Vingt Regards sur l'Enfant-Jésus, Paris: Durand S.A. (Görselin ilk kısmı Messiaen'ın partisyonundan alınmış, ikinci kısmı ise tema baz alınarak bizim tarafımızdan oluşturulmuştur.)

Görsel 5. Messiaen, O. (1944). Vingt Regards sur l'Enfant-Jésus, Paris: Durand S.A. (Görseldeki ölçüler Messiaen'ın partisyonundan alınmış, kutular ve çözümleyici işaretler ise bizim tarafımızdan eklenmiştir.)

Görsel 6. Messiaen, O. (1944). Vingt Regards sur l'Enfant-Jésus, Paris: Durand S.A. (Görsel, söz konusu ölçülerin sol elindeki ritmik malzeme baz alınarak bizim tarafımızdan oluşturulmuştur.)

Görsel 7. Messiaen, O. (1944). Vingt Regards sur l'Enfant-Jésus, Paris: Durand S.A. (Görseldeki ölçüler Messiaen'ın partisyonundan alınmış, kutular bizim tarafımızdan eklenmiştir.) 
Görsel 8. Messiaen, O. (1944). Tecnica del mio linguaggio musicale, çev. Lucia Ronchett, Paris: Alphonse Leduc. (Kaynağın 10. sayfasındaki görsel baz alınarak tarafımızdan oluşturulmuştur.)

Görsel 9. Messiaen, O. (1944). Vingt Regards sur l'Enfant-Jésus, Paris: Durand S.A; Baggech, M. (1998). An English Translation of Olivier Messiaen's Traite de rythme, de couleur, et d'ornithologie, Yayınlanmamış Doktora Tezi, 1. Cilt, Norman: The University of Oklahoma. (Yukarıdaki ritim partisyondan, aşağıdaki ritim Baggech'in çevirisinden alınmış; çözümleyici işaretler tarafımızdan eklenmiştir.)

Görsel 10. Messiaen, O. (1944). Vingt Regards sur l'Enfant-Jésus, Paris: Durand S.A. (Görsel, söz konusu ölçülerin sol elindeki ritmik malzeme baz alınarak bizim tarafımızdan oluşturulmuştur.)

Görsel 11. Messiaen, O. (1944). Vingt Regards sur l'Enfant-Jésus, Paris: Durand S.A. (Görseldeki ölçüler Messiaen'ın partisyonundan alınmış, rakamlarsa bizim tarafımızdan eklenmiştir.)

Görsel 12. Messiaen, O. (1944). Tecnica del mio linguaggio musicale, çev. Lucia Ronchett, Paris: Alphonse Leduc. (Kaynaktan alınan görsele bizim tarafımızdan kutu eklenmiştir.) 